\title{
Químicos Recebem Prêmio por Desenvolver um Processo de Reciclagem de Óleo de Fritura para Produção de Tinta de Impressão
}

por Paulo A. Z. Suarez
Data de publicação na Web: 27 de Dezembro de 2011 Recebido em 25 de Dezembro de 2011 Aceito para publicação em 26 de Dezembro de 2011
Os químicos Vinícius Mello e Guilherme Bandeira receberam o Prêmio Abrafati-Petrobras de Ciência em Tintas (13a edição). A Abrafati é a Associação Brasileira de Fabricantes de Tintas. Este prêmio é o resultado das pesquisas realizadas por estes dois pósgraduandos no Laboratório de Materiais e Combustíveis do Instituto de Química da Universidade de Brasília, sob a orientação do Prof. Paulo A. Z. Suarez, para reaproveitar o óleo gerado em cozinhas domésticas e industriais, o qual é tido como um dos principais poluentes responsáveis pelo entupimento de encanamentos e ralos, e por dificultar o tratamento de esgotos e poluir rios e reservatórios de água.

A solução apontada pela equipe foi a produção de tintas de impressão para processos offset (processo usado para impressões em larga escala de, por exemplo, jornais e revistas). Como subproduto do processo, Mello e Bandeira obtiveram hidrocarbonetos leves que podem ser usados como combustíveis líquidos ou solventes. O processo é simples. $\mathrm{Na}$ presença de um complexo de metal de transição que age com catalisador, o óleo é aquecido a $300{ }^{\circ} \mathrm{C}$ e começa a polimerizar. Assim, as moléculas que compõem o óleo residual começam a se ligar, aumentando de tamanho, até chegar a polímeros com alta viscosidade.
Para se produzir a tinta, basta misturar pigmentos (sólidos insolúveis que fornecem a cor) e pequenas quantidades de óleo de soja ou de fritura ao polímero. A função do polímero na tinta vai ser a de manter o pigmento agregado e grudado à superfície do papel. Aumentando-se a temperatura começam a ser formados hidrocarbonetos leves, que evaporam rapidamente e podem ser condensados para se obter uma mistura de hidrocarbonetos com 5 a 10 átomos de carbono. Esta mistura de hidrocarbonetos leves pode ser usada como combustível líquido ou solvente. Quanto maior a temperatura, maior será a quantidade de hidrocarboneto leve formado e menor a de polímero. Acima de 370 ํC já não há formação de polímeros e todo óleo residual é transformado em hidrocarbonetos leves. Dependendo do produto desejado, pode-se modular a proporção entre polímero e hidrocarbonetos leves apenas variando a temperatura entre 300 e $370 \stackrel{\circ}{\circ}$. Foram obtidas tintas de impressão de forma artesanal no laboratório com diferentes teores de pigmentos. As propriedades físico-químicas dessas tintas mostram o potencial da tecnologia utilizada. Na Figura 1 aparece digitalizado um papel impresso com uma tinta produzida de forma artesanal a partir do polímero de óleo residual e negro de fumo (pigmento).
Obviamente, há outras propostas para aproveitamento de óleo residual no mercado, principalmente de companhias de saneamento urbano, para que cooperativas de catadores de lixo passem a coletá-lo. Dentre essas tecnologias, pode-se destacar o uso para produção de sabão, massa de vidraceiro e biodiesel, as quais, entretanto, agregam pouco valor ao óleo residual. Diferente das demais, a tecnologia desenvolvida por Vinícius e Guilherme leva a um produto de alto valor agregado, o que irá contribuir para que as ações de reciclagem do óleo encontrem viabilidade econômica e, assim, se consiga finalmente encontrar um destino adequado para este passivo ambiental.

Vinicius Mello é Bacharel em Química e Mestre em FísicoQuímica pela UnB e, atualmente, é aluno do curso de Doutorado na mesma instituição.

Guilherme Bandeira é Bacharel em Química e esta finalizando o seu mestrado em Físico-Química na UnB.

Paulo Suarez é Engenheiro Químico, Mestre em Química e Doutor em Ciências dos Materiais pela UFRGS, bolsista de produtividade no nível ID do $\mathrm{CNPq}$ e Professor Adjunto do Instituto de Química da UnB.

Paulo A. Z. Suarez gostaria de agradecer à EMPRABA pelo financiamento da pesquisa e ao CNPq pela bolsa de pesquisador. 


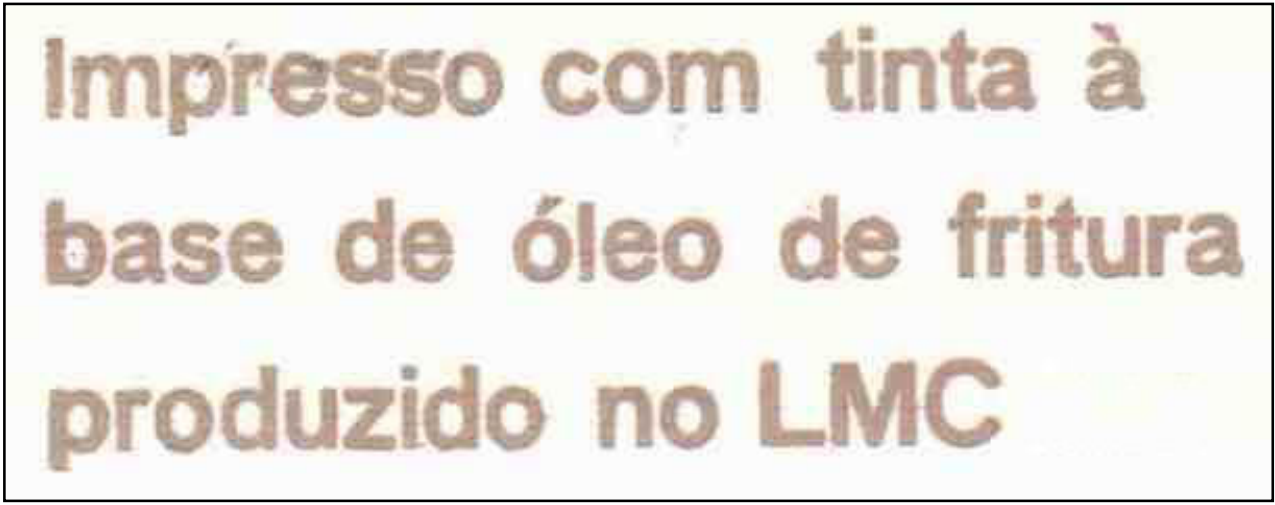

Figura 1. Impresso usando tinta produzida com óleo residual

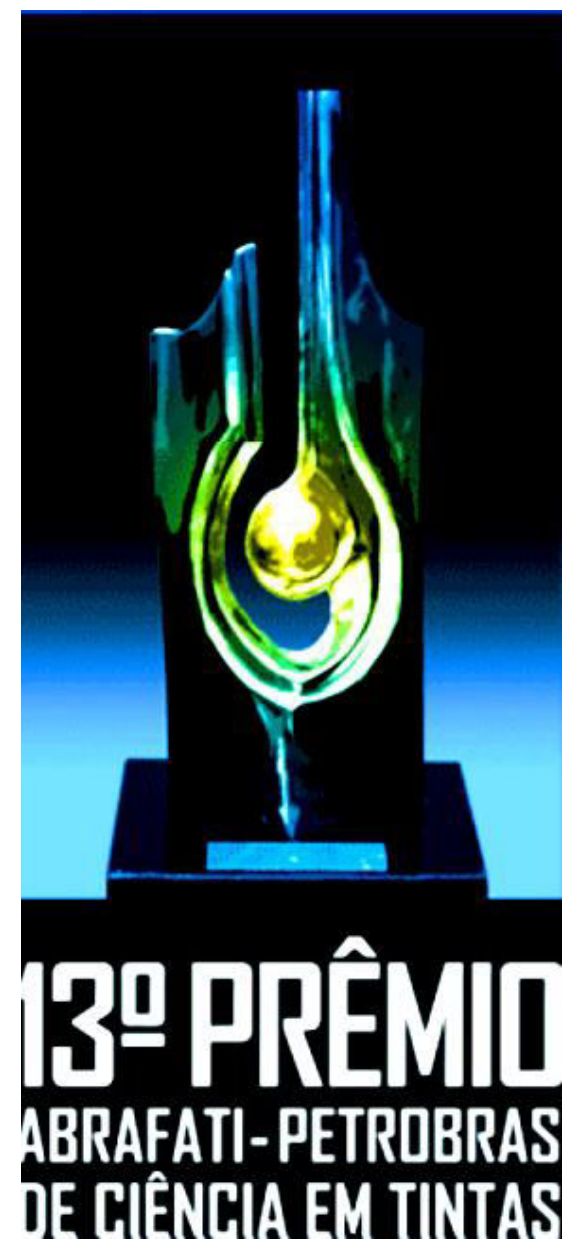

Universidade de Brasília, Instituto de Química, Laboratório de Materiais e Combustíveis, CP 4478, CEP 70.904970, Brasília/DF, Brasil.

Mpsuarez@unb.br 